進行上部胃癌に対する摘脾, 膵体尾部温存術式の検討

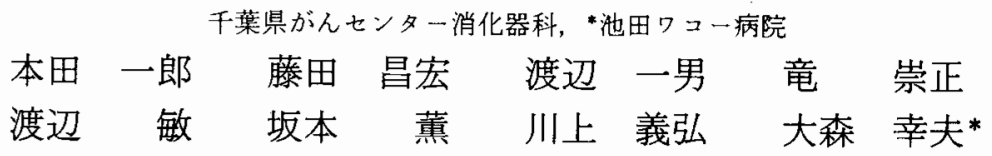

\title{
STUDIES ON SPLENECTOMY AND PANCREAS PRESERVING OPERATION FOR ADVANCED UPPER GASTRIC CARCINOMA
}
Ichiro HONDA, Yohihiro FUJITA, Kazuo WATANABE, Munemasa RYU, Satoshi WATANABE, Kaoru SAKAMOTO and Yoshihiro KAWAKAMI

Division of Gastroenterology, Chiba Cancer Center Hospital

Yukio OMORI

Ikeda Wako Hospital

\begin{abstract}
進行上部胃癌に対する膵体尾部温存術の適応の有無を検討した。対象は治癒切除のなされた143例で ある. (11)番リンパ節の郭清は $\mathrm{S}_{2}$ とい党ども脾動脈幹切除により残った膵体尾部の半連続切片に上る検 索でもリンパ節が見られず，また転移りンパ節からの膵実質浸潤もないので可能である、 $\mathrm{S}_{2}$ 例の潜在 性脺実質浸潤は7.3\%にすぎない，したがって $\mathrm{S}_{2}$ 例の大半は膵体尾部温存術の適応がある. $\mathrm{S}_{3}$ (膵), および明らかな(11番転移を有する例，また，潜在性の腹膜再発の危険のあるものには膵脾合併切除術 では不十分で, 治癒切除が望めるのなら左上腹部蔵器全摘術を行らべきと考学る。いずれにしろ $\mathrm{S}_{2}$ に 対する処置が重要である。
\end{abstract}

索引用語：進行上部胃癌, 膵体尾部温存術, 脾動脈幹切除

はじめに

進行上部胃癌には脺脾合併，胃全摘術が標準術式と して定着し, 広く施行されている。近年, 丸山1゙により 提唱された脾動脈幹切除により 111番リンパ節郭清が出 来る「膵体尾温存術」は膵脾合併切除と同じ郭清効果 があり，しかも膵体尾部の温存ができるためいわゆる 「縮小」手術の対象として早期癌や予後的漛膜面因子 $\left(\right.$ ）例 $=\mathrm{PS}(-)$ ，を中心に増加の傾向にある ${ }^{2)}$. 進行 上部癌に対する本術式の適応について臨床病理学的に 検討した。

\section{検討の対象}

1973年 1 月〜1988年12月未までに千葉県がんセン

*第33回日消外会総会シンポI・進行胃癌の手術術式 そその根拠

$<1989$ 年 5 月 8 日受理 >別刷請求先：本田 一郎

7280 千葉市仁戸名町666-2 千葉県がんセンター 消化器科
ターで切除された 1,407 例の初発胃癌のらち治癒切除 のなされた143例の上部癌と, 非治癒切除に終った23例 の膵脾合併切除例である。

上部胃癌の切除術式

$$
\text { 結果 }
$$

上部胃癌では $\mathrm{R}_{1}$ の手術に終る噴門側切除術や単純 胃全剔術は当然のことながら早期癌を中心とする壁深 達度の浅いPS (一) 例に適応があり, 両術式を施行し た54例中 PS（十）例は 4 例にすぎなかった。膵体尾部 温存術は22例に施行され 5 例 $(22.7 \%)$ が PS (十) で ある．膵脾合併切除術は67例に行われ46例 $(68.7 \%)$ がPS（十）となっている。このように膵脾合併切除術 は治癒切除とはいえPS（十）のよらなかなりの進行癌 に施行されてきている(表1).

リンパ節転移度

(10)番, (11)番郭清のなされた治癒切除上部胃癌例のリ ンパ節転移度を示す。早期癌を除く PS ( - ) 23例の転 
表 1 上部胃癌の切除術式

\begin{tabular}{|c|c|c|c|c|c|}
\hline & 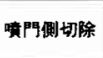 & 章維全捅 & 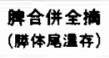 & 䑏解含伴切除 & it \\
\hline $\begin{array}{c}m \\
s \\
s m\end{array}$ & 18 & 17 & 8 & 5 & 48 \\
\hline$\underset{\substack{\text { pm } \\
\text { ss-B }}}{ }$ & 6 & 9 & 9 & 16 & 40 \\
\hline PS $(+)$ & $\begin{array}{c}3 \\
(11.1 \%)\end{array}$ & $\begin{array}{c}1 \\
(3.7 \%)\end{array}$ & $\begin{array}{c}5 \\
(22.7 \%)\end{array}$ & $\begin{array}{c}46 \\
(68.7 \%)\end{array}$ & 55 \\
\hline 計 & 27 & 27 & 22 & 67 & 143 \\
\hline
\end{tabular}

( ) PS(+)の占める籼合

図 1 上部胃癌のリンパ節転移度

Ps (-) : $n=23$

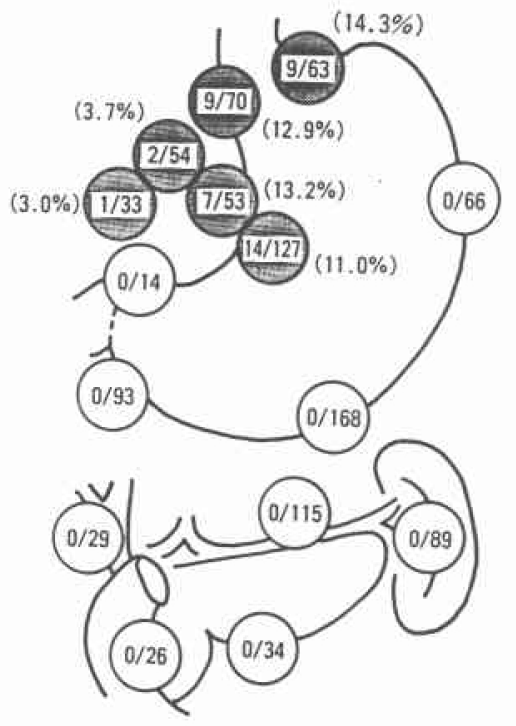

移度は，(1)番 $12.9 \%$, (2)番 $14.3 \%$, (3)番 $11.0 \%$, (7)番 $13.2 \%$ ，8番3.0\%，(9)番3.7\%であるが(10)番, (11)番に は転移が見られないので進行癌とはい学 PS (一)例で は膵体尾部はもちろんのこと脾臓の温存も可能であ る.さらに，(4d)，(5)，(6)番リンパ節に転移が見られな いので肛門側断端 (AW) が限局型で $2 \mathrm{~cm}$, 浸潤型で5 $\mathrm{cm}$ 以上とれれば噴門側切除も可能である(図 1).PS （十）38例ではリンパ節転移が広範となり(10番 $11.7 \%$, (11)番 $10.8 \%$ の転移度を見る。この事実と(11)番 sampling の膵体尾部の半連続切片による検索咕によれば， samplingの倍近いリンパ節および転移リンパ節の追加が 得られることが脺体尾部切除の理論的根拠の 1 つで あった（図 2 ).

脾動脈幹切除について
図 2 上部胃癌のリンパ節転移

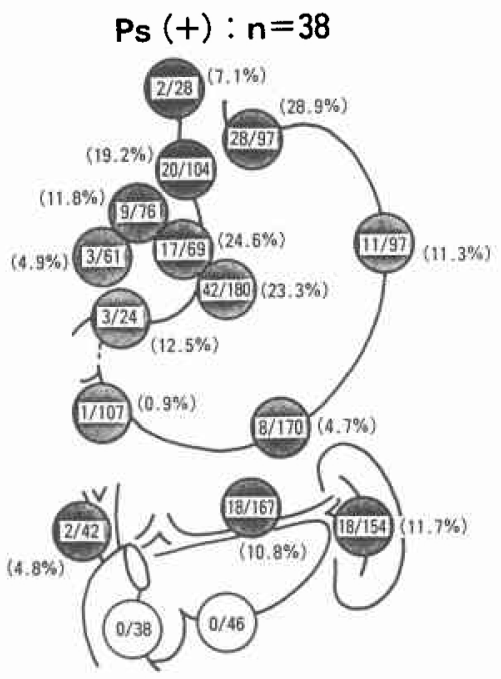

上記のごとく(11)番リンバ節の完全郭清には膵体尾部 切除が不可欠とされていた。 丸山による脾動脈幹切除 は郭清効果, および藏器温存の面からすれば画期的な 方法である，PS (十) 例にも十分適応のあることを半 連続切片による検索にて行った。 症例は $\mathrm{S}_{2}(\mathrm{PS}(+))$ 3 例で, 局在は $\mathrm{C}$, 後壁 大弯中心で $\mathrm{S}_{2}$ の長径が $4 \mathrm{~cm}$ 以上の $\mathrm{N}_{2}(+)$ 例である。1 1 例が $\mathrm{N}_{11-\mathrm{A}}(+)$ である. まず肉眼的に sampling で捨い出した17個の(11)番リン パ節で $\mathrm{N}_{11}(+) は 1$ 例，1個であったが，組織学的に は 3 個，2 例に転移がみられた。ささらに脾動脈幹の 半連続切片による検索では22個のリンパ節の追加があ り N $11 \cdot \mathrm{A}(+)$ 例にさらに 1 個の転移リンパ節を検出し た。したがって囵番の転移度は $10.3 \%$ となり図 2 の PS (十) 例の $10.8 \%$ とほとんど同じである. 次に膵体 尾部の半連続切片による検索によれば, 膵体尾部には リンパ節は全く見られず脾動脈幹切除により(11番リン パ節は完全に郭清されていた。 加らるに, 転移リンパ 節怙よび $\mathrm{S}_{2}$ からの膵被膜一実質浸潤も見られなかっ た（図 3，表 2).

転移リンパ節からの脺実質浸潤

(11)番転移リンパ節からの膵実質浸潤例を示す（表 3). 非治㾤切除例は $\mathrm{P}_{0}, \mathrm{H}_{0}$ で $\mathrm{N}>\mathrm{R}$ により非治癒と なっている８８例すべて目転移を有し，乙かも単独 のものはなく(3)，(7)，(9)番などと一塊となったもので $\mathrm{N}_{3}(+)$ 以上である.このような例のうち 6 例 $(75.0 \%)$ に転移リンパ節より膵実質浸潤がみられた。しかし， 治瘾切除の(11)番転移単独の 4 例 $(22.2 \%)$ からの脺実 
図 3 (10), (11)番：半連続切片による検索

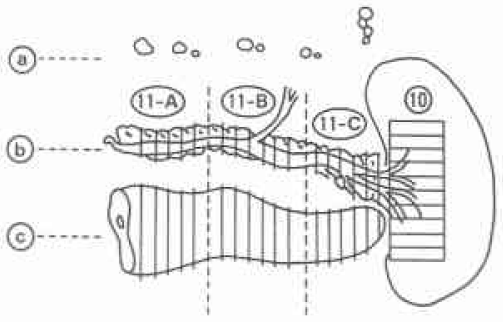

表 2 10，(11)番：半連続切片による検索

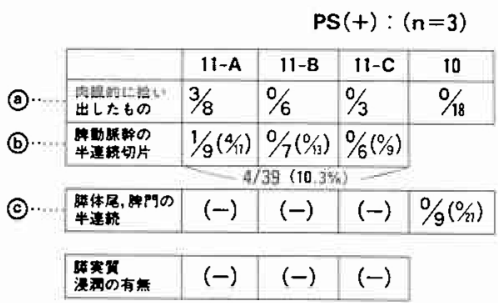

※(C)操作を行っても，膵体尾にりンパ節の遺残もな く，また，膵実質漫潤も見られない。

表 $3 \mathrm{PS}(+)$ : 膵実質浸潤の有無 $\left(\mathrm{S}_{2}\right.$ の長径 $4 \mathrm{~cm}$ 以 上) (膵, 脾合併切除例)

\begin{tabular}{|c|c|c|c|c|c|c|}
\hline & \multicolumn{2}{|c|}{10 番 } & \multicolumn{2}{|c|}{ ii 番 } & \multicolumn{2}{|c|}{ 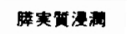 } \\
\hline 有 & $(t)$ & $(-)$ & $(+)$ & $(-)$ & $(t)$ & $(-)$ \\
\hline $\begin{array}{l}\text { 治荡切除 } \\
(n=1)\end{array}$ & $\begin{array}{c}5 \\
(27.8 \%)\end{array}$ & $\begin{array}{c}13 \\
(72.2 \%)\end{array}$ & $\begin{array}{c}4 \\
(22.2 \%)\end{array}$ & $\begin{array}{c}14 \\
(77.8 \%)\end{array}$ & 0 & 18 \\
\hline $\begin{array}{c}\text { 非治虔切除 } \\
(\mathrm{n}=8)\end{array}$ & $\begin{array}{c}7 \\
(87.5 \%)\end{array}$ & $\begin{array}{c}1 \\
(12.5 \%)\end{array}$ & $\begin{array}{c}8 \\
(100 \%)\end{array}$ & & 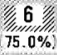 & $\begin{array}{c}2 \\
(25.0 \%)\end{array}$ \\
\hline
\end{tabular}

表 4 膵被膜への癌浸潤

\begin{tabular}{|c|c|c|c|c|}
\hline \multirow{2}{*}{ hist. } & \multicolumn{2}{|c|}{ Ca. infilt (t) } & \multirow{2}{*}{$\underset{(-)}{\text { Ca. infilt }}$} & \multirow{2}{*}{ it } \\
\hline & Capsel & $\underset{\text { Papsel } \longrightarrow \text { Patinym }}{\longrightarrow}$ & & \\
\hline \multirow{2}{*}{$\mathbf{s}_{3}$} & 5 & 4 & \multirow{2}{*}{11} & \multirow{2}{*}{20} \\
\hline & \multicolumn{2}{|c|}{$9(45 \%)$} & & \\
\hline \multirow{2}{*}{$S_{1 \sim \underline{2}}$} & 6 & 3 & \multirow{2}{*}{32} & \multirow{2}{*}{41} \\
\hline & \multicolumn{2}{|c|}{$9(22 \%)$} & & \\
\hline if & \multicolumn{2}{|c|}{$18(30 \%)$} & 43 & 61 \\
\hline
\end{tabular}

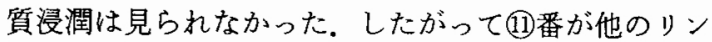
ハ節と一塊の非治癒切除例は $\mathrm{S}_{3}$ に準じてしかるべき と考える。また明らかな(11)番りンパ節転移がなければ たとえ組織学的に(11)番転䔟はあっても膵被膜 $\rightarrow$ 実質浸 潤がみられないので脾動脈幹切除による(11)番郭清の適 応之考える。

潜在性の脺被膜および実質浸潤

膵体尾部切除のなされた $\mathrm{S}_{1 \sim 2}$ 41例, $\mathrm{S}_{3} 21$ 例につい て S からの膵被膜 $\rightarrow$ 実質浸潤の有無を示す(表 4 ). 組
表 5 上部贯癌の再発型式

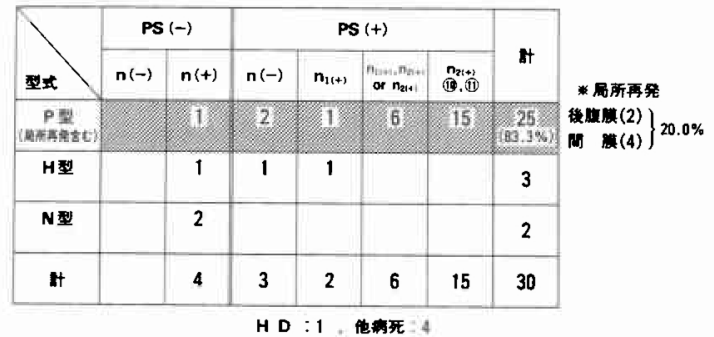

織学的には全例 PS $(+)$ である、 $\mathrm{S}_{3}$ は膵体尾部切除の 絶対適応であるが被膜浸潤は20例中 9 例 $(45 \%)$ に見 られ実質浸潤本であるものは4例（20\%）であった。 $\mathrm{S}_{1 \sim 2}$ の PS (十) 41例では 9 例 $(22.0 \%)$ に被膜浸潤かj 又られ 3 例 $(7.3 \%)$ が実質浸閏を有していた。このこ とが脺体尾部切除のもら一つの根拠であった。しかし， 膵実質浸潤まで及ぶ $\mathrm{S}_{1 \sim 2}$ 例は $\mathrm{S}_{2}$ が広範囲で, しか子腫 境の局在が後壁から大弯, 組織型が低分化のものであ り, その再発型式は結腸間膜再発, すなわら局所の P

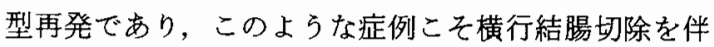
与左上腹部臟器全摘術の適応と考える.

再発型式

治癒切除のなされた上部胃癌の再発型式を示す（表 5 ). 死亡例は35例で他病死 4 例, 入院死亡 1 例を除い た 30 例の再発をみると，局所再発を含む腹膜再発が25 例 $(83.3 \%$ ) と圧倒的に多く，他は肝転移 2 例，骨転 移 1 例の $\mathrm{H}$ 型 (血行再発) で $\mathrm{N}$ 型 (リンパ節再発) は 2 例にすぎな，局所再発は結腸間膜再発が 4 例, 後 腹膜再発が 2 例, 計 6 例 $(20.0 \%)$ であり，先の潜在 性の $\mathrm{P}$ 型再発と合わせて考えると膵体尾部切除では 不充分であろう。また，21例 $(63.3 \%)$ が P 型再発死 をしていることが治癒切除とはいえ $\mathrm{S}_{2}$ (PS $\left.(+)\right)$ 例 の予後を悪くしていると思える。

\section{$\mathbf{P}_{0} ， \mathbf{H}_{0}$ 症例に対する抗癌剤の腹腔内投与}

治癒切除とはい光 PS $(+)$ 脺脾合併切除の予後は悪 く stage III の 5 年累積生存率は $23.7 \%(n=45)$ にす ぎず，その大半を $\mathrm{P}$ 型再発で失っているのが現況であ る. $\mathrm{P}_{0}, \mathrm{H}_{0}, \mathrm{~S}_{2}$ 症例に対し以前より M.M.C. (mitomycin c)などの腹腔内投与が試みられてきたが投与量, 方法 の問題もあり，いまだに定説をみない，温熱化学療法 もさまざまな報告があるが手技，装置の面で一般化し ておらず，確かに有効とは思えるが経験がないのでコ メントはさけたい. 最近, C.D.D.P. (cisplatin)の癌性 腹膜炎に対する有効例の報告が見られるようになっ 
図 4 抗癌風の腹腔内投与

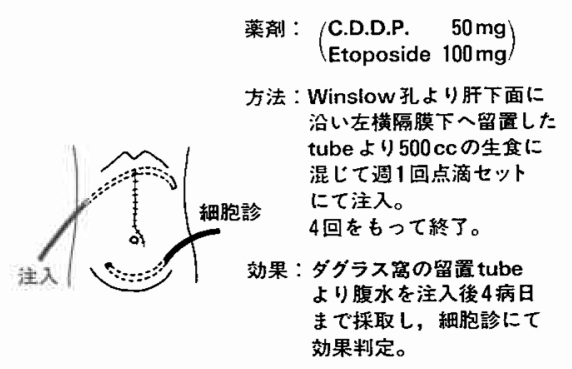

表 6 抗癌剂の腹空内投与

\begin{tabular}{|c|c|c|c|c|c|c|}
\hline 症䣦 & 性 & 組織型 & 梁達度 & $n$ & 注入前|終了時 & “術式 \\
\hline 1 & $F$ & por & se & $n_{x}$ & $V \rightarrow \| b$ & st \\
\hline 2 & $M$ & sa & se & $n_{3}$ & $\mathrm{IV} \rightarrow \mathrm{Ha}$ & Pst \\
\hline 3 & $F$ & por & ss $\gamma$ & $n_{2}$ & $\mathrm{IIJ} \mathbf{b} \rightarrow \mathrm{II} a$ & st \\
\hline 4 & $F$ & por & se & $n_{2}$ & $\mathrm{~V} \rightarrow \mathrm{I} \mathbf{b}$ & Pst \\
\hline 5 & $F$ & por & se & $n_{2}$ & $\mathrm{II} \mathbf{b} \rightarrow \mathrm{II} \mathbf{a}$ & st \\
\hline 6 & $F$ & por & se & $n_{2}$ & $\mathrm{v} \rightarrow \mathrm{H} \mathbf{a}$ & Pst \\
\hline 7 & $M$ & por & se & $\mathrm{n}_{4}$ & $\mathrm{v} \rightarrow \mathrm{II} b$ & Pst \\
\hline 8 & $M$ & tub $_{2}$ & se & $n_{4}$ & III $b \rightarrow$ IIa & st \\
\hline
\end{tabular}

た4)。そこで図4のごとく，手術終了時 Winslow 孔よ り左横隔膜下おょび Dauglas窩の 2 か所に留置 チューブを置さ, C.D.D.P. とVP-16 (etoposide) の腹 腔内投与を試みている。効果判定はDauglas 窩留置 チューブよりの吸引細胞診にて行っている.

Stage III, IV の $\mathrm{P}_{0}, \mathrm{H}_{0}, \mathrm{~S}_{2} 8$ 例に施行した(表6). 術式は膵脾合併，膵体尾部温存ともに 4 例で $\mathrm{n}_{4}(+)$ の 2 例が相対非治癒切除泈っている. 8 例中 7 例が 術直後の細胞診で class IIIb〜Vであったが，4回注入 後は悪性細胞はみられなくなった。このことが長期子 後につながるか否かはいまだ最長生存例が 8 か （tumor free）なので結論は控えたい.

\section{考察}

進行上部胃癌に対する萃脾合併, 胃全摘術は四半世 紀の間定型術式として定着している。リンパ節郭清の 範囲が第 4 群（大動脈周囲リンパ節）に至り $\mathrm{N}$ 型再発 に対する外科治療一手術手技の進歩一は遅々としてい るが確実にあると思える。しかし，このようにリンパ 節郭清の手をのばしても膵脾合併, 胃全摘術の予後の 向上は見られない.膵体尾部切除の理由は，(1)， $\mathrm{S}_{3}$ (膵) の除去, (2), (11)番リンパ節の郭清, (3), 潜在性の膵被 膜〜実質浸潤の除去にあった． $\mathrm{S}_{3}$ (膵) に関しては絶 対適応であることはいうまでもなく，明らかな(11)番転 移からのいわば $\mathrm{S}_{3}$ (11番) む膵体尾部切除の適応であ
る.しかしこのような症例は stage IVが大半であり, かつ広範なリンパ節転移を有し, かつ $\mathrm{S}_{3}$ の連続進展, 潜在性の腹膜播種の可能性を含むであろう。このよう な症例に膵脾合併切除だけでよいであろらか? 症例 の背景は局在が後壁から大弯で $\mathrm{S}_{2}$ が広範囲, 肉眼型が 3〜 4 型の浸潤型で組織型が低分化型で治癒切除上部 癌例の $10 \%$ 以下であり，このよらな例こそ左上腹部臓 器合摘術を行うべきであろう。したがって $\mathrm{S}_{2}$ 症例の大 半は11番郭清の面でも，潜在性の脺被膜浸潤一実質浸 潤の面からも膵体尾部切除の必要はない.すなわち, 脾動脈幹切除により完全に(11)番リンパ節は郭清でき, 明らかな肉眼的(11)番転移 $\left(\mathrm{N}_{11}(+)\right.$ を除く組織学的(11) 番転移リンパ節からの萃被膜〜実質浸潤はなく，かつ $\mathrm{S}_{2}$ からの潜在性の膵被膜一串質浸潤例は左上腹部臓 器全摘術の適応症例に挙げた条件を満たするのであ り，それ以外のものは潜在性の膵実質浸潤がないので 脺体尾部の温在は進行癌とはいえ十分に可能である. つまり, 膵脾合併, 胃全摘術は搪大手術之縮小手術の 狭間に位置するものであり，今後は進行上部胃癌に対 し安易に施行すべきではないと考光る。いずれにして も PS（十）の進行上部胃癌では手術効果をあげるため に, $\mathrm{S}_{2}$ からの腹膜再発の予防処置が大切であり, 治療 体系の確立を切望する。

\section{結 語}

1. 進行上部胃癌では $\mathrm{S}_{3}$ (膵)，打よび明らかなる(11) 番リンパ節転移例を除けば, $\mathrm{P}_{0}, \mathrm{H}_{0}, \mathrm{~S}_{2}$ 症例でも膵体 尾部の温存は可能である。

2. $\mathrm{S}_{3}$ (膵)，明らかなる(11)番りンパ節転移を有する 癌腫の局在が後壁〜大弯, 肉眼型が $3 \sim 4$ 型で組織型 が低分化のものは左上腹部蔵器全摘の適応と考元る。

3. $\mathrm{P}_{0}, \mathrm{H}_{0}, \mathrm{~S}_{2}$ 症例には潜在性の腹膜播種に対する処 置が重要かつ急務である。

\section{文献}

1) 丸山圭一：脾動脈幹リンパ節廊清に膵尾合併切除 は不可欠であろらか? 一膵温存手術の適応と臨床 成績一. 日消外会誌 $12: 961-965,1979$

2) 大森幸夫, 本田一郎：噴閇癌手術における術式の 選択一とくに治療成績から一, 消外 10 ： 953-959, 1987

3) 金井 弘：胃癌に対する萃体尾切除剔脾合併手術 の意義. 日癌治療会誌 $2: 328-338,1967$

4) 山田哲司, 大平政樹, 是島 寛ほか：癌性腹膜炎に 対するC.D.D.Pの腹腔内投与. 癌と化療 13 ： 1004-1008, 1986 